\title{
Independent validation of downscaled climate estimates from a coastal Alaska watershed using local historical weather journals
}

\author{
Emily R Williamson ${ }^{\text {Corresp., }}{ }^{,}$, Christopher J Sergeant ${ }^{1,2}$ \\ ${ }^{1}$ College of Fisheries and Ocean Sciences, University of Alaska - Fairbanks, Fairbanks, Alaska, United States \\ 2 Flathead Lake Biological Station, University of Montana, Polson, Montana, United States \\ Corresponding Author: Emily R Williamson \\ Email address: erwilliamson3@alaska.edu
}

Downscaling coarse global and regional climate models allows researchers to access weather and climate data at finer temporal and spatial resolution, but there remains a need to compare these models with empirical data sources to assess model accuracy. Here, we validate a widely used software for generating North American downscaled climate data, ClimateNA, with a novel empirical data source, 20th century weather journals kept by Admiralty Island, Alaska homesteader, Allen Hasselborg. Using Hasselborg's journals, we calculated monthly precipitation and monthly mean of the maximum daily air temperature across the years 1926 to 1954 and compared these to ClimateNA data generated from the Hasselborg homestead location and adjacent areas. To demonstrate the utility and potential implications of this validation for other disciplines such as hydrology, we used an established regression equation to generate time series of $95 \%$ low duration flow estimates for the month of August using mean annual precipitation from ClimateNA predictions and Hasselborg data. Across 279 months, we found strong correlation between modeled and observed measurements of monthly precipitation ( $\rho=$ $0.74)$ and monthly mean of the maximum daily air temperature $(\rho=0.98)$. Monthly precipitation residuals (calculated as ClimateNA data - Hasselborg data) generally demonstrated heteroscedasticity around zero, but a negative trend in residual values starting during the last decade of observations may have been due to a shift to the coldphase Pacific Decadal Oscillation. Air temperature residuals demonstrated a consistent but small positive bias, with ClimateNA tending to overestimate air temperature relative to Hasselborg's journals. The degree of correlation between weather patterns observed at the Hasselborg homestead site and ClimateNA data extracted from spatial grid cells across the region varied by wet and dry climate years. Monthly precipitation from both data sources tended to be more similar across a larger area during wet years (mean $\rho$ across grid cells $=0.73$ ) compared to dry years (mean $\rho$ across grid cells $=0.65$ ). The time series of annual Peer] reviewing PDF | (2021:03:59360:1:1:NEW 13 Jul 2021) 
95\% low duration flow estimates for the month of August generated using ClimateNA and Hasselborg data were moderately correlated $(\rho=0.55)$. Our analysis supports previous research in other regions which also found ClimateNA to be a robust source for past climate data estimates. 


\section{Independent validation of downscaled climate}

2 estimates from a coastal Alaska watershed using local

3 historical weather journals

4

5

6

7

8

Emily R. Williamson ${ }^{1}$, Christopher J. Sergeant ${ }^{1,2}$

${ }^{1}$ College of Fisheries and Ocean Sciences, University of Alaska Fairbanks, Alaska, USA

${ }^{2}$ Flathead Lake Biological Station, University of Montana, Montana, USA

Corresponding Author:

Emily R. Williamson ${ }^{1}$

2150 Koyukuk Drive, Fairbanks, Alaska, 99775-7220, USA

Email address: erwilliamson3@alaska.edu

\section{Abstract}

Downscaling coarse global and regional climate models allows researchers to access weather and climate data at finer temporal and spatial resolution, but there remains a need to compare these models with empirical data sources to assess model accuracy. Here, we validate a widely used software for generating North American downscaled climate data, ClimateNA, with a novel empirical data source, 20th century weather journals kept by Admiralty Island, Alaska homesteader, Allen Hasselborg. Using Hasselborg's journals, we calculated monthly precipitation and monthly mean of the maximum daily air temperature across the years 1926 to 1954 and compared these to ClimateNA data generated from the Hasselborg homestead location and adjacent areas. To demonstrate the utility and potential implications of this validation for other disciplines such as hydrology, we used an established regression equation to generate time series of $95 \%$ low duration flow estimates for the month of August using mean annual precipitation from ClimateNA predictions and Hasselborg data. Across 279 months, we found strong correlation between modeled and observed measurements of monthly precipitation ( $\rho=$ $0.74)$ and monthly mean of the maximum daily air temperature $(\rho=0.98)$. Monthly precipitation residuals (calculated as ClimateNA data - Hasselborg data) generally demonstrated heteroscedasticity around zero, but a negative trend in residual values starting during the last decade of observations may have been due to a shift to the cold-phase Pacific Decadal Oscillation. Air temperature residuals demonstrated a consistent but small positive bias, with ClimateNA tending to overestimate air temperature relative to Hasselborg's journals. The degree of correlation between weather patterns observed at the Hasselborg homestead site and ClimateNA data extracted from spatial grid cells across the region varied by wet and dry climate years. Monthly precipitation from both data sources tended to be more similar across a larger area during wet years (mean $\rho$ across grid cells $=0.73$ ) compared to dry years (mean $\rho$ across 
40 grid cells $=0.65$ ). The time series of annual $95 \%$ low duration flow estimates for the month of

41 August generated using ClimateNA and Hasselborg data were moderately correlated $(\rho=0.55)$.

42 Our analysis supports previous research in other regions which also found ClimateNA to be a

43 robust source for past climate data estimates.

44

\section{Introduction}

46 Across many scientific disciplines, researchers rely on the downscaling of coarse global and

47 regional climate models to access weather and climate data at finer temporal and spatial

48 resolution (Mote and Salathé 2010; Xu et al. 2019). While weather stations collect accurate local

49 measurements, they are not evenly distributed and leave many empirical data gaps across the

50 globe. Statistical downscaling of weather measurements such as rainfall or air temperature, rather

51 than empirical observations, is one of several methods available for analyzing climate and

52 hydrologic response in remote regions where station maintenance is difficult and expensive.

53 ClimateNA is a widely used, publicly available, and user-friendly software that produces a suite

54 of statistically downscaled monthly and annual climate variables for point locations across North

55 America that are dynamically adjusted for local elevation (Wang et al. 2016). The software's

56 simplicity and wide range of historical and future time ranges lends itself well to correlating

57 climate patterns with questions related to many environmental science disciplines. A recent study

58 demonstrated that monthly temperature variables generated by ClimateNA performed well

59 against measured data from 232 weather stations in southern Alberta, Canada, but some biases

60 existed across space, season, and elevation (Roberts et al. 2019). In this study, climate data

61 generated by ClimateNA provide the basis for our validation with a novel source of empirical

62 weather data from sub-arctic Alaska. While global climate model performance for this region has

63 been compared to re-analysis products that combine weather observations with numerical

64 modeling (for example, see Herzfeld et al. 2007 and Walsh et al. 2008), very few climate model

65 validation efforts are based solely on independent empirical observations.

66

67

68

69

70

71

72

73

74

75

76

77

78

79

In Alaska, air temperatures are expected to rise over time alongside increases in annual precipitation and extreme precipitation (Lader et al. 2017). In remote regions such as our study location in Southeast Alaska, USA, downscaled projections of temperature, precipitation, and snowfall are critical to understanding regional hydrology and ecology (Bieniek et al. 2016; Littell et al. 2018). For example, combining river basin topography with estimates of monthly precipitation allows for the calculation of various hydrologic metrics such as percentile flow magnitudes (Wiley and Curran 2003), which directly relate to the efficacy of burgeoning hydropower operations (Cherry et al. 2017) and the population dynamics of many aquatic organisms (Poff et al. 1997; Brown, 2016). The success of culturally and economically valuable fish populations in Alaska such as Pacific salmon (Oncorhynchus spp.) is inextricably tied to flow regimes (Schoen et al. 2017; Johnson et al. 2019); therefore, having access to high-quality climate information is critical for resource managers and users to assess habitat conditions over time and the potential for future change. 
80

81 Climate change is occurring rapidly in Southeast Alaska. Regional experts predict increases in

82

83

84

85

86

87

88

89

90

91

92

93

94

95

96

97

98

99

100

101

102

103

104

105

106

107

108

109

110

111

112

113

114

115

116

117

118

119 annual average air temperature and precipitation, with less precipitation falling as snow during the fall and winter (Shanley et al. 2015; Littell et al. 2018; Lader et al. 2020). A key challenge is determining the rate at which these changes are occurring, thus it is important to compare contemporary climate trends with historical data sets. Historical climate time series derived from direct measurement methods are often sparse in remote locations. In these instances, downscaled data can be used to estimate climate metrics across large scales of time and space, but their local accuracy is difficult to determine without validation using independent empirical data. This is especially challenging in topographically complex areas like Southeast Alaska, where mountains rise from sea level to hundreds of meters above sea level within a few $\mathrm{km}$. This steep topography promotes orographic lifting, which raises moist air and condenses it into precipitation. A mosaic of mountains, glaciers, and narrow marine passages create dynamic micro-climates combining wet and mild coastal zones with drier and colder continental conditions (Shanley et al. 2015), making it difficult to discern the accuracy of downscaled climate patterns relative to nearby weather stations. For example, in a validation study of the North American arctic, modeled climate accuracy was variable across seasons and better at predicting air temperature than precipitation (Herzfeld et al. 2007). Since downscaling creates a high-resolution grid of interpolated data, the quality of digital elevation models used has a direct bearing on data quality. In steep terrain, the grid cell of a coarse elevation model may span hundreds of meters of elevation and lead to misleading or difficult-to-interpret data outputs. ClimateNA addresses this issue through a combination of bilinear interpolation and elevation adjustments that allows users to extract data from a specific point in space that is not averaged over an entire grid cell (Wang et al. 2016).

Considering the difficulty in predicting climate patterns for a geographically complex region, the extent to which downscaled climate models can be corroborated with conventional weather measurements will improve the confidence of research and regional decision-making based mostly on modeling efforts. Here, we present a novel validation of downscaled climate data from 1926 to 1954 using archived weather journals from Admiralty Island, Alaska homesteader, Allen Hasselborg. Daily weather observations were collected by Hasselborg at his homestead adjacent to Mole Harbor and the Mole River, located on the eastern shoreline of Admiralty Island in Southeast Alaska (Figures 1 and 2). During the years 1926-1954 covered by his journals, only 7 weather stations existed in the region, with the nearest in Juneau approximately $74 \mathrm{~km}$ away. Mole Harbor remains uninhabited to the present day.

Southeast Alaska is situated in the northern portion of the Pacific Coastal Temperate Rainforest, a generally mild and wet maritime landscape averaging $200 \mathrm{~cm}$ of precipitation per year (O'Neel et al. 2015). The maximum elevation within the $67 \mathrm{~km}^{2}$ Mole River watershed is $869 \mathrm{~m}$ while mean elevation is $272 \mathrm{~m}$. With no glaciers present in its drainage area, the Mole River is a mostly 
120 forested watershed with discharge driven by a combination of rain and snow runoff (a "rain-

121

122

123

124

125

126

127

128

129

130

131

132

133

134

135

136

137

138

139

140

141

142

143

144

145

146

147

148

149

150

151

152

153

154

155

156

157

158

159

snow-I" watershed as defined in Sergeant et al. 2020). Rain-snow-I watersheds are found throughout the coastal Gulf of Alaska. While maximum discharge tends to occur in mid-March for this watershed class, the flow regime of the Mole River remains unmeasured and maximum discharge could potentially occur during any day of the year (Sergeant et al. 2020).

Our primary objective was to determine how closely weather observations from Hasselborg's journals correlated with monthly climate observations extracted from ClimateNA (Wang et al. 2016) at the same location and time periods. We then mapped the degree of correlation between the weather journals and modeled climate data across varying distances from the homestead site and elevations. We calculated residuals between observed and modeled values of monthly precipitation and monthly mean of the daily maximum air temperature to determine whether the accuracy of modeled data changed over time. To demonstrate the application of this research to other disciplines such as hydrology and fish biology, we compare streamflow metrics derived from the journals and modeled data.

\section{Materials \& Methods}

\section{Data acquisition}

Data were acquired from an interactive climate model platform and Hasselborg's handwritten weather journals. The widely used software, ClimateNA (Version 6.2; Wang et al. 2016), generates statistically downscaled climate estimates for any 4 x $4 \mathrm{~km}$ grid cell in North America, with customizable variables such as spatial coordinates, elevation, and date range. ClimateNA can generate precipitation and temperature data with monthly to annual resolution. The software incorporates and interpolates historical data spanning from 1901 to the present day, as well as a suite of general circulation models for future predictions. Hasselborg's data were not used to generate historical data in ClimateNA and are therefore an independent source for model validation. We obtained monthly precipitation and monthly mean of the daily maximum air temperature values from the approximate GPS coordinates for Mole Harbor (57.647541, 134.094391). We allowed ClimateNA to determine elevation automatically. This provided model estimates overlapping with all of Hasselborg's recorded years (1926-1954).

Hasselborg recorded daily temperature and precipitation between 1926 and 1954 at approximately sea-level near the mouth of the Mole River (Figures 1 and 2). Missing time periods spanned July-September 1931, August-September 1932, June 1933, and December 1933 to January 1938. Hasselborg's original handwritten weather journals are archived at the Alaska State Library and Archives in Juneau, Alaska, USA (Figure 2). Journals were scanned as images and manually transcribed into a Microsoft Excel spreadsheet. The lead author (ERW) transcribed daily maximum air temperature (converted from ${ }^{\circ} \mathrm{F}$ to ${ }^{\circ} \mathrm{C}$ ) and monthly precipitation (converted from in to $\mathrm{mm}$ ). Hasselborg recorded precipitation in 0.25 in fractions, and recorded even and

Peer] reviewing PDF | (2021:03:59360:1:1:NEW 13 Jul 2021) 
160

161

162

163

164

165

166

167

168

169

170

171

172

173

174

175

176

177

178

179

180

181

182

183

184

185

186

187

188

189

190

191

192

193

194

195

196

197

198

199

odd integers for temperature in his journals until 1933. It is possible that after a break from journaling from 1933 to 1938, Hasselborg used a second thermometer or changed his protocol for temperature measurements as nearly all post-1938 temperatures are even integers. To our knowledge, Hasselborg did not provide notes on his temperature collection methods. We also do not know if his thermometer was shielded from sunlight. We hypothesized that he collected maximum daily air temperature because this is the most logical consistent measurement that could be collected from an analog thermometer without having to collect measurements at the exact same time each day. Subsequent analyses in the Results section support this hypothesis. We excluded unreadable journal days or entries with multiple measurements. We also do not know for certain whether Hasselborg included snow in his precipitation amounts, but based on journal pages where he makes separate notes for rain and snow, we believe he intended to only measure rain. This does not exclude the possibility of some error due to snow falling into the measurement tool along with rain during winter months.

\section{Correlation analysis}

For monthly precipitation and monthly mean of the maximum daily air temperature measurements, we trimmed the ClimateNA data to account for Hasselborg's data gaps ( $n=279$ usable months for precipitation, $n=274$ usable months for temperature), and calculated a Spearman's rank correlation coefficient $(\rho)$ for the complete time series of empirical and modeled data. To assess spatial correlation at increasing distances from the Mole River watershed, we mapped the correlation between Hasselborg's monthly precipitation data and ClimateNA datasets for the wettest year (1939) and the driest year (1951) found in his journals. Centroid coordinates for each grid cell in the spatial correlation map were spaced 0.2 decimal degrees longitude and 0.1 decimal degrees latitude apart and originated from the Hasselborg homestead.

To determine whether ClimateNA displayed seasonal or annual trends in estimating observed weather values, residuals were calculated across the entire time series by subtracting the monthly values for both precipitation and temperature measured by Hasselborg from those estimated by ClimateNA. To visually assess trends in the time series of residuals, we implemented a loess smoother, a non-parametric form of local regression where points are weighted based on their distance from the observation of interest (Jacoby 2000). Residuals were also averaged across the four meteorological seasons: winter (DJF), spring (MAM), summer (JJA), and fall (SON).

\section{Application of climate data sources to estimating streamflow descriptors}

Low-duration streamflow was estimated using precipitation, watershed basin area, and watershed elevation in a regression equation derived from streamflow gage data (Wiley and Curran 2003).

To demonstrate the application of our validation to useful hydrologic estimates, we calculated the annual 95th percentile low-duration flow for August (AUG95) in $\mathrm{ft}^{3} / \mathrm{s}$ using the following equation: 
200

201

202

203 Where,

$204 \mathrm{~A}=$ watershed drainage area $\left(\mathrm{mi}^{2}\right)$

$205 \mathrm{P}=$ mean annual precipitation (in)

$206 \mathrm{E}=$ mean basin elevation $(\mathrm{ft})$

207

208

209

210

211

212

213

214

215

216

217

218

219

220

221

222

223

224

225

226

227

228

229

230

231

232

233

234

235

236

237

238

239 1932, 1933, 1946).

\section{Results} relative to Hasselborg's journals (Figure 4).

AUG95 estimates in $\mathrm{ft}^{3} / \mathrm{s}$ were then converted to $\mathrm{m}^{3} / \mathrm{s}$.

The Wiley and Curran (2003) equation typically uses, "mean annual precipitation averaged over the drainage basin," but in order to facilitate a more direct streamflow comparison between ClimateNA data and the Hasselborg journals, we only extracted mean annual precipitation each year from ClimateNA using the coordinates of the Hasselborg homestead. This approach assumes that modeled or observed precipitation amounts from the homestead site were comparable to average conditions across the basin. We did not estimate low-duration August flow during years where Hasselborg skipped $>3$ months of precipitation measurements. Hasselborg skipped one to three months per year for four of the included years in the data (1931,

We found strong correlation $(\rho)$ between the monthly precipitation time series generated from modeled (ClimateNA) and empirical (Hasselborg's journals) climate data $(\rho=0.74, \mathrm{P}<<0.001$; Figure 3). Residual values of modeled - observed monthly precipitation data ranged from 189 $\mathrm{mm}$ to $-412 \mathrm{~mm}$ with a mean of $-14.4 \mathrm{~mm}$ (Figure 3 ). In general, residuals demonstrated heteroscedasticity around the zero line for the vertical axis, but there was evidence of a negative trend in residual values starting during the last decade of data (Figure 3). Hasselborg's precipitation values had a greater range than Climate NA, which consistently overestimated monthly precipitation when Hasselborg observed less than $50 \mathrm{~mm}$ and underestimated when observations were greater than $400 \mathrm{~mm}$ (Figure 3).

There was high correlation between monthly means of the maximum daily air temperature generated from ClimateNA and observed by Hasselborg $(\rho=0.98, \mathrm{P}<<0.001$; Figure 4$)$. The residual values of modeled - observed monthly mean of the maximum daily temperature data ranged from $-3.06{ }^{\circ} \mathrm{C}$ to $10.44^{\circ} \mathrm{C}$ with a mean of $0.77^{\circ} \mathrm{C}$ (Figure 4). Residuals demonstrate a consistent but small positive bias, with ClimateNA tending to overestimate air temperature

When the distributions of precipitation residuals were summarized across meteorological seasons, ClimateNA was less accurate with a more precise range of values in the summer relative 
240 to the other seasons, when precipitation was generally underestimated and demonstrated greater 241 variability (Figure 5). The distributions of seasonal residuals of temperature demonstrated an 242 opposite pattern to precipitation (Figure 5). ClimateNA overestimated the most during winter243 and to a lesser extent, spring and fall — while summer months were most closely correlated.

244

245

246

247

248

249

250

251

252

253

254

255

256

257

258

259

260

261

262

263

264

265

266

267

268

269

270

271

272

273

274

275

276

277

278

279

The degree of correlation between weather patterns observed at the Hasselborg homestead site and ClimateNA data extracted from spatial grid cells across the region varied by wet and dry climate years (Figures 6 and 7). Monthly precipitation from ClimateNA tended to be more similar to empirical data collected by Hasselborg across a larger area during wet years compared to dry years. During the wettest year recorded in Hasselborg's journals, 1939, mean $\rho=0.73$ (SD $=0.11$ ) across all grid cells (Figure 6). For the driest journal year, 1951, mean $\rho=0.65$ (SD $=$ 0.14 ) across all grid cells (Figure 7). For both years, correlations between ClimateNA and Hasselborg's data tended to be strongest in areas of low to mid-elevation. Correlations were weakest in high elevation areas and icefields across both years, but correlations were especially weak along the continental mainland during the dry year of 1951. During 1939, correlations were generally very high for grid cells south of the Hasselborg homestead.

The time series of annual $95 \%$ low duration flow estimates for the month of August generated using ClimateNA and Hasselborg data were moderately correlated ( $\rho=0.55, \mathrm{P}=0.007$; Figure 8). While the directional trends in both time series were comparable across time, similar to the spatial correlation maps (Figures 6 and 7), ClimateNA estimates of low duration flow tended to be further from estimates using Hasselborg observations during dry years such as 1951 .

\section{Discussion}

With an ever-growing need to compare the changes in the earth's climate from historical times to present-day, validation of climate models with empirical data will continue to be an essential aspect of environmental research. Historical weather measurements collected from remote locations have the potential to underestimate actual conditions (Baudouin 2020) and be of questionable quality. To our knowledge, Hasselborg's Mole River data set did not include a second observer or provide any methodological accounting. Despite these limitations, the corroboration of Hasselborg's data and downscaled estimates produced from ClimateNA suggests that both sources are generally reliable. Since our analysis covers only a very small geographic area, we caution that our results should not be generalized beyond the northern portion of the Southeast Alaska panhandle. In western North America, there are many more examples of inter-model comparisons of climate data (for example, Jiang et al. 2018) instead of the validation with empirical data presented here. Although a validation of ClimateNA across broader spatial scales using additional empirical data was beyond the scope of our study, a logical next step would be to use data from other historical weather stations using similar methods. Reviewing publicly available records through the National Weather Service (https://w2.weather.gov/climate/xmacis.php?wfo=pajk), we determined the nearest weather

Peerj reviewing PDF | (2021:03:59360:1:1:NEW 13 Jul 2021) 
280

281

282

283

284

285

286

287

288

289

290

291

292

293

294

295

296

297

298

299

300

301

302

303

304

305

306

307

308

309

310

311

312

313

314

315

316

317

318

319

station with temperature and precipitation data overlapping with Hasselborg's journals was in Juneau, approximately $74 \mathrm{~km}$ away. Other overlapping data are available from Haines, Little Port Walter, Petersburg, Sitka, Skagway, and Yakutat and range 100-300 km from the Hasselborg homestead. We do not know the extent to which these data are independent from ClimateNA generated data.

Similar to the findings of Herzfeld et al. (2007) in the North American arctic, modeled air temperature data were more strongly correlated with observed data than precipitation. We also found support for the reliability of ClimateNA estimates in low-lying maritime environments throughout the northern portion of the Alaska Panhandle (Southeast Alaska), and correlations across space with Hasselborg's data were especially strong during a wet year. In southern Alberta, Canada, Roberts et al. (2019) found that ClimateNA performed well against air temperature variables collected across 232 weather stations, but downscaled values tended to overestimate temperature at higher $(>2000$ meters above sea level) and lower $(<1000$ meters above sea level) elevations. A consistent theme in our work and others cited herein is that recognizing and potentially correcting model biases are critical for the practical application of climate downscaling in fields such as ecology (Roberts et al. 2019). We are not aware of any other validations of ClimateNA using historical and independent empirical data.

The southern coastal region of Alaska is undergoing shifts in climate that impact the ecology of the region (Shanley et al. 2015). As a snow- and rain-driven system, the Mole River is representative of many low-lying watersheds throughout Southeast Alaska. Watersheds to the south and west of Mole River are primarily rain-driven, relatively lower elevation, and more exposed to maritime influence (Sergeant et al. 2020). This may explain the high correlation between Hasselborg and ClimateNA data in the southern portion of our study region during the wet year of 1939. Although adjacent watersheds should have similar climate patterns to the Mole River, we urge researchers to use caution when applying downscaled climate data to other ecological and physical estimates, especially in higher elevation watersheds with snow and glacier runoff patterns. While the August low streamflow descriptor we derived from empirical and modeled data followed the same general directional patterns over time, there were significant differences in the estimates of flow magnitude, especially during dry years such as 1951 . This might be explained by long-range atmospheric drivers such as the Pacific Decadal Oscillation (PDO). The negative trend in modeled precipitation residuals during the final decade of data (1944-1954), correspond with a shift to a cold-phase PDO. This may be coincidental timing or it may be due to local variability in topographically complex terrain that is difficult to model correctly during oscillation shifts. In Southeast Alaska, the cold-phase PDO typically translates to more winter precipitation falling as snow than rain and resulting in higher-than-average summer discharge (Mantua et al. 1997; Neal et al. 2002). Patterns such as these are important context for researchers applying downscaled climate data and suggest that further validation research is necessary across a broader range of elevational and latitudinal gradients. 


\section{1}

322

323

324

325

326

327

328

329

330

331

332

333

334

335

336

337

338

339

340

341

342

343

344

345

346

347

348

349

350

351

352

353

354

355

356

357

358

\section{Acknowledgements}

We thank Uma Bhatt and Rick Lader for advice and helpful reviews of preliminary manuscript drafts. We thank David Roberts and Michael Winfree for thoughtful and constructive peer reviews that greatly improved the final manuscript. Sandra Johnston at the Alaska State Library and Archives provided access and scanning tools for Hasselborg's journals.

\section{References}

Baudouin, J. P., Herzog, M., \& Petrie, C. A. (2020). Cross-validating precipitation datasets in the Indus River basin. Hydrology \& Earth System Sciences, 24(1).

Bieniek, P. A., Bhatt, U. S., Walsh, J. E., Rupp, T. S., Zhang, J., Krieger, J. R., \& Lader, R. (2016). Dynamical downscaling of ERA-Interim temperature and precipitation for Alaska. Journal of Applied Meteorology and Climatology, 55(3), 635-654.

Brown, L. R., Komoroske, L. M., Wagner, R. W., Morgan-King, T., May, J. T., Connon, R. E., \& Fangue, N. A. (2016). Coupled downscaled climate models and ecophysiological metrics forecast habitat compression for an endangered estuarine fish. PloS one, 11(1), e0146724.

Cherry, J. E., Knapp, C., Trainor, S., Ray, A. J., Tedesche, M., \& Walker, S. (2017). Planning for climate change impacts on hydropower in the Far North. Hydrology and Earth System Sciences, 21(1), 133-151.

Herzfeld, U. C., Drobot, S., Wu, W., Fowler, C., \& Maslanik, J. (2007). Spatiotemporal Climate Model Validation-Case Studies for MM5 over Northwestern Canada and Alaska. Earth Interactions, 11(20), 1-23.

Jacoby, W. G. (2000). Loess:: a nonparametric, graphical tool for depicting relationships between variables. Electoral Studies, 19(4), 577-613.

Jiang, Y., Kim, J. B., Still, C. J., Kerns, B. K., Kline, J. D., \& Cunningham, P. G. (2018). Intercomparison of multiple statistically downscaled climate datasets for the Pacific Northwest, USA. Scientific data, 5(1), 1-18.

Johnson, A. C., Bellmore, J. R., Haught, S., \& Medel, R. (2019). Quantifying the monetary value of Alaska national forests to commercial Pacific salmon fisheries. North American Journal of Fisheries Management, 39(6), 1119-1131. 
359

360

361

362

363

364

365

366

367

368

369

370

371

372

373

374

375

376

377

378

379

380

381

382

383

384

385

386

387

388

389

390

391

392

393

394

395

396

397

398

Lader, R., Bidlack, A., Walsh, J. E., Bhatt, U. S., \& Bieniek, P. A. (2020). Dynamical downscaling for Southeast Alaska: Historical climate and future projections. Journal of Applied Meteorology and Climatology, 59(10), 1607-1623.

Lader, R., Walsh, J. E., Bhatt, U. S., \& Bieniek, P. A. (2017). Projections of twenty-first-century climate extremes for Alaska via dynamical downscaling and quantile mapping. Journal of Applied Meteorology and Climatology, 56(9), 2393-2409.

Littell, J. S., McAfee, S. A., \& Hayward, G. D. (2018). Alaska snowpack response to climate change: Statewide snowfall equivalent and snowpack water scenarios. Water, 10(5), 668.

Mantua, N. J., Hare, S. R., Zhang, Y., Wallace, J. M., \& Francis, R. C. (1997). A Pacific interdecadal climate oscillation with impacts on salmon production. Bulletin of the american Meteorological Society, 78(6), 1069-1080.

Neal, E. G., Walter, M. T., \& Coffeen, C. (2002). Linking the pacific decadal oscillation to seasonal stream discharge patterns in Southeast Alaska. Journal of Hydrology, 263(1-4), 188197.

Mote, P. W., \& Salathé, E. P. (2010). Future climate in the Pacific Northwest. Climatic change, 102(1-2), 29-50.

O'Neel, S., Hood, E., Bidlack, A. L., Fleming, S. W., Arimitsu, M. L., Arendt, A., ... \& Pyare, S. (2015). Icefield-to-ocean linkages across the northern Pacific coastal temperate rainforest ecosystem. BioScience, 65(5), 499-512.

Poff, N. L., Allan, J. D., Bain, M. B., Karr, J. R., Prestegaard, K. L., Richter, B. D., ... \& Stromberg, J. C. (1997). The natural flow regime. BioScience, 47(11), 769-784.

Roberts, D. R., Wood, W. H., \& Marshall, S. J. (2019). Assessments of downscaled climate data with a high-resolution weather station network reveal consistent but predictable bias.

International Journal of Climatology, 39(6), 3091-3103.

Schoen, E. R., Wipfli, M. S., Trammell, E. J., Rinella, D. J., Floyd, A. L., Grunblatt, J., ... \& Witmer, F. D. (2017). Future of Pacific salmon in the face of environmental change: Lessons from one of the world's remaining productive salmon regions. Fisheries, 42(10), 538-553.

Sergeant, C. J., Falke, J. A., Bellmore, R. A., Bellmore, J. R., \& Crumley, R. L. (2020). A classification of streamflow patterns across the coastal Gulf of Alaska. Water Resources Research, 56(2), e2019WR026127.

Peer) reviewing PDF | (2021:03:59360:1:1:NEW 13 Jul 2021) 
399

400 Shanley, C. S., Pyare, S., Goldstein, M. I., Alaback, P. B., Albert, D. M., Beier, C. M., ... \&

401 Wipfli, M. S. (2015). Climate change implications in the northern coastal temperate rainforest of 402 North America. Climatic Change, 130(2), 155-170.

403

404 Walsh, J. E., Chapman, W. L., Romanovsky, V., Christensen, J. H., \& Stendel, M. (2008).

405 Global climate model performance over Alaska and Greenland. Journal of Climate, 21(23),

406 6156-6174.

407

408 Wang, T., Hamann, A., Spittlehouse, D., \& Carroll, C. (2016). Locally downscaled and spatially 409 customizable climate data for historical and future periods for North America. PloS one, 11(6), $410 \mathrm{e} 0156720$.

411

412 Wiley, J.B., and Curran, J.H., 2003, Estimating annual high-flow statistics and monthly and 413 seasonal low-flow statistics for ungaged sites on streams in Alaska and conterminous basins in 414 Canada: U.S. Geological Survey Water-Resources Investigations Report 03-4114, 61 p.

415

416 Xu, Z., Han, Y., \& Yang, Z. (2019). Dynamical downscaling of regional climate: A review of 417 methods and limitations. Science China Earth Sciences, 62(2), 365-375. 


\section{Figure 1}

Study area.

The Mole River watershed (gray polygon) and the location of Allen Hasselborg's homestead (black dot). 


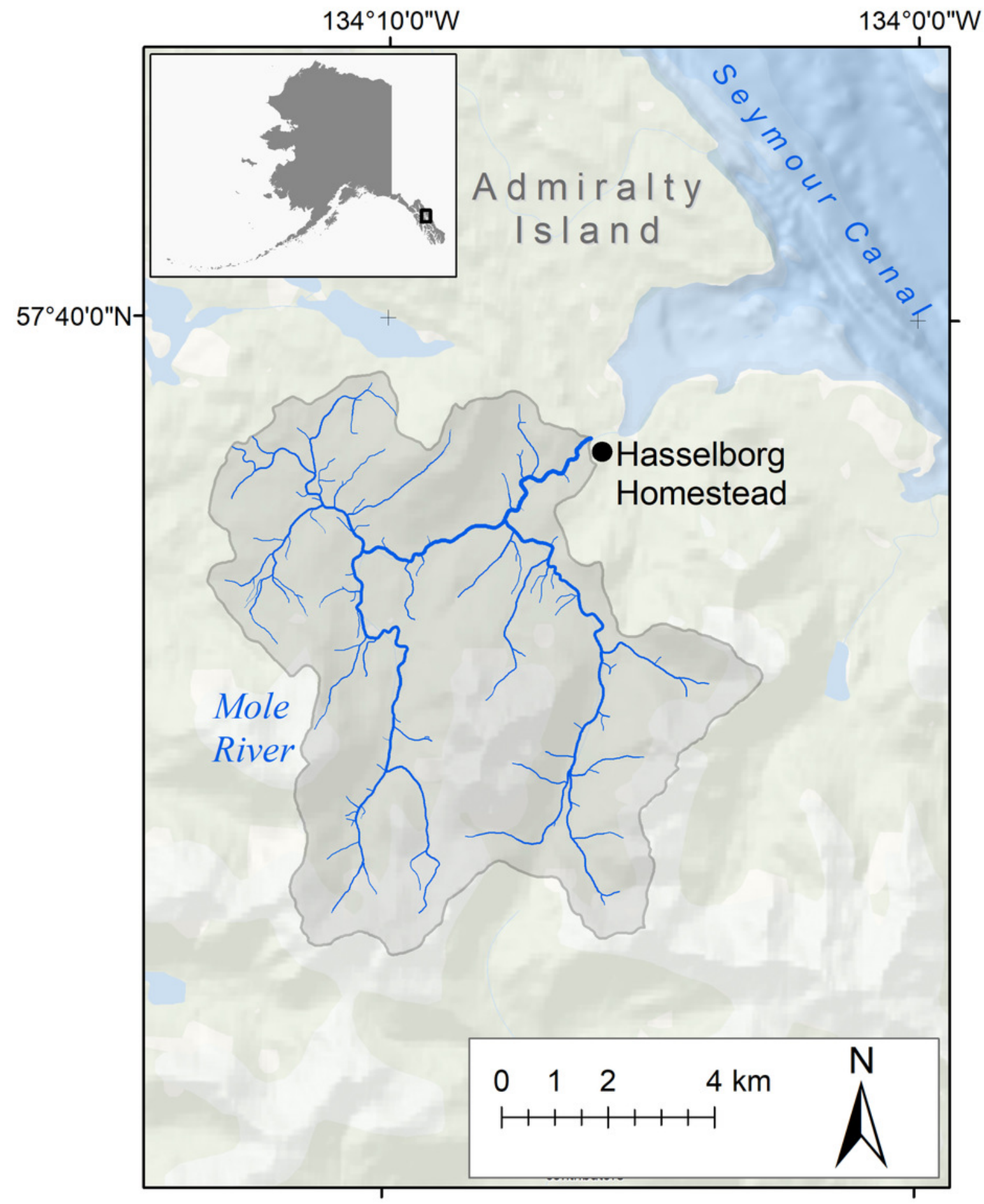




\section{Figure 2}

The journals of Allen Hasselborg.

(A) Example pages from Allen Hasselborg's weather journals. In the upper left corner of each page, note that Hasselborg summed total monthly precipitation in inches. In the third column of each page, Hasselborg provided a symbol describing weather conditions that day: clear (open circle), cloudy (cross), rain (upward facing arch), or snow (downward facing arch). (photo credit: lead author, ERW). (B) Hasselborg at his homestead next to Mole River in 1941 (Image accessed through the Alaska Digital Archives,

https://vilda.alaska.edu/digital/collection/cdmg21/id/12774/rec/23).

A
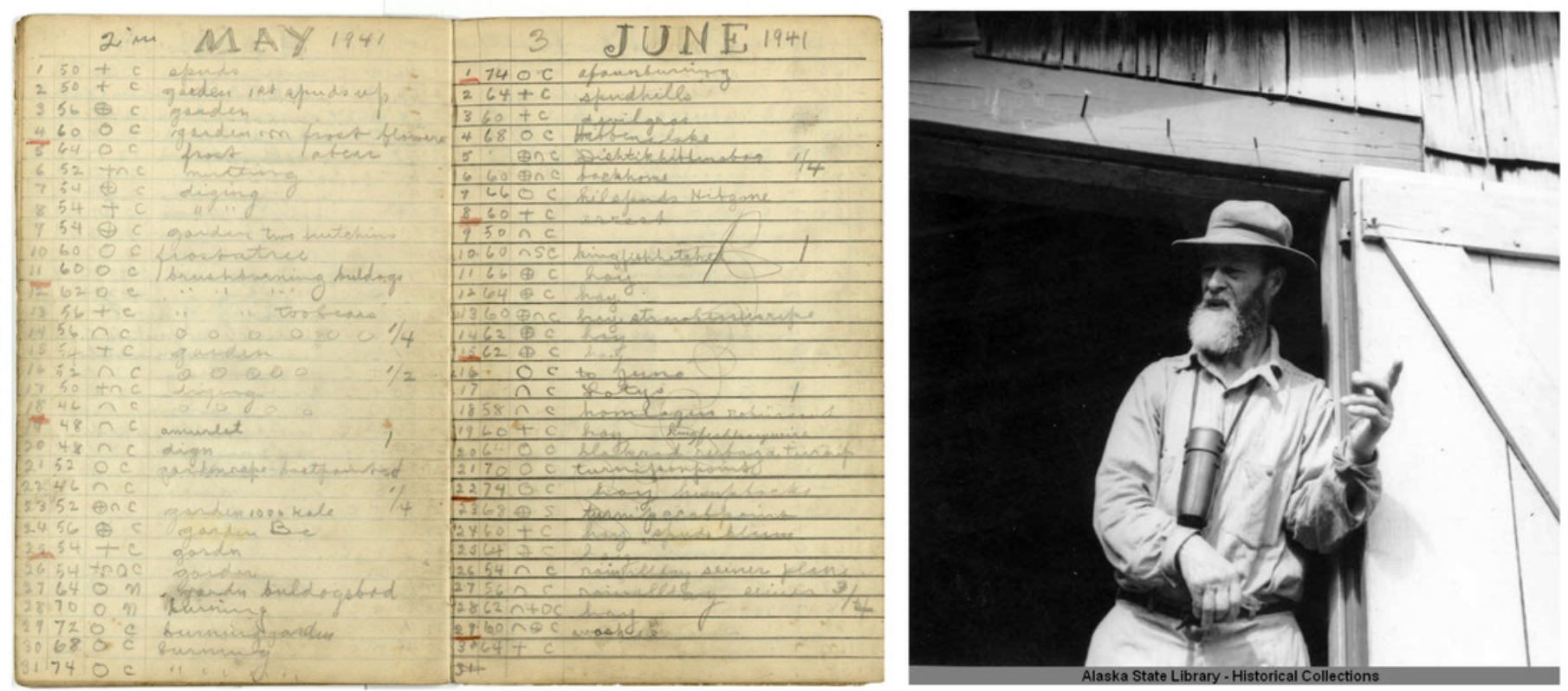
Figure 3

Time series and residuals of modeled and observed precipitation data.

(A) Monthly precipitation estimated by ClimateNA (orange) compared with monthly precipitation measured by Hasselborg (blue). (B) Residuals of monthly precipitation. A loess smoothed trend line with span $=0.75$ (blue) is included along with a dotted reference line at $y=0$.
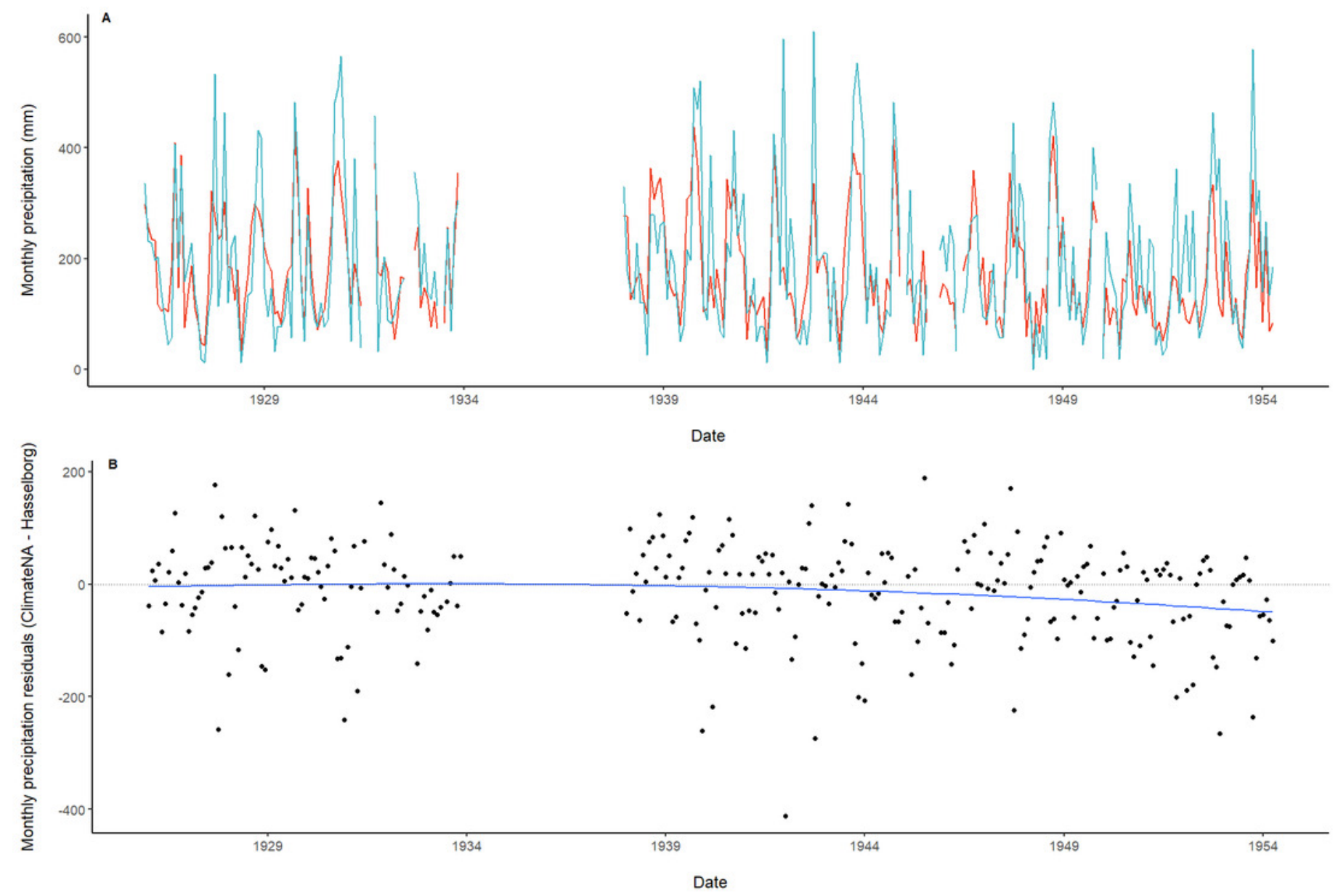
Figure 4

Time series and residuals of modeled and observed temperature data.

(A) Monthly mean of the daily maximum temperature estimated by ClimateNA (orange) compared with Hasselborg (blue) (B) Monthly mean of the daily maximum temperature residuals. A loess-smoothed trend line with span $=0.75$ (blue) is included along with a dotted reference line at $y=0$. 

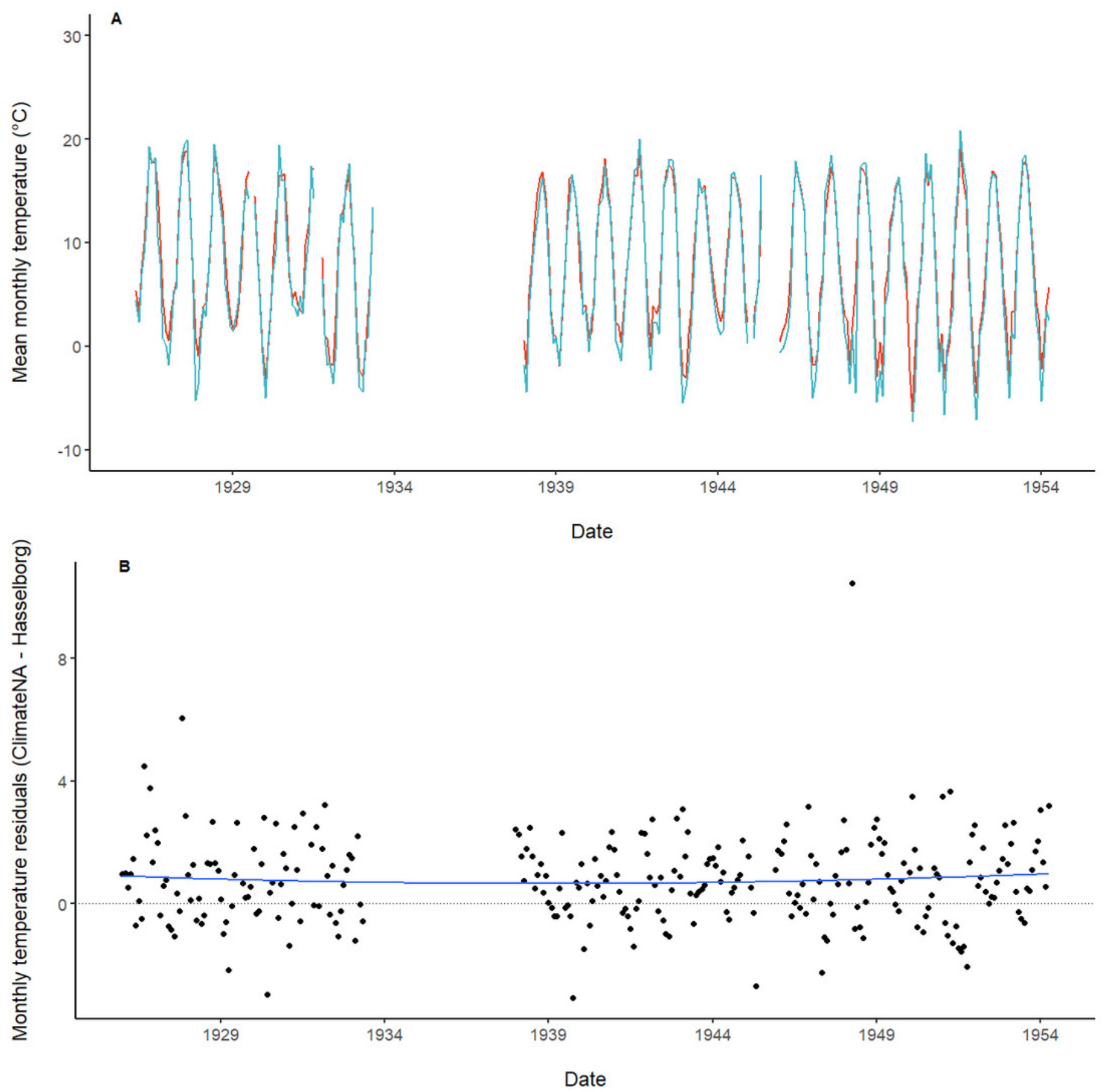


\section{Figure 5}

Boxplots of seasonal residuals

Boxplots of residuals aggregated by meteorological season for $(A)$ monthly precipitation and (B) monthly mean of the daily maximum temperature. Black lines in the middle of each box represent median values. The top and bottom lines of each box represent 75 th and 25 th percentiles, respectively. The ends of the whiskers represent $1.5 \times$ the interquartile range. Individual letters along the horizontal axis represent months of the year.
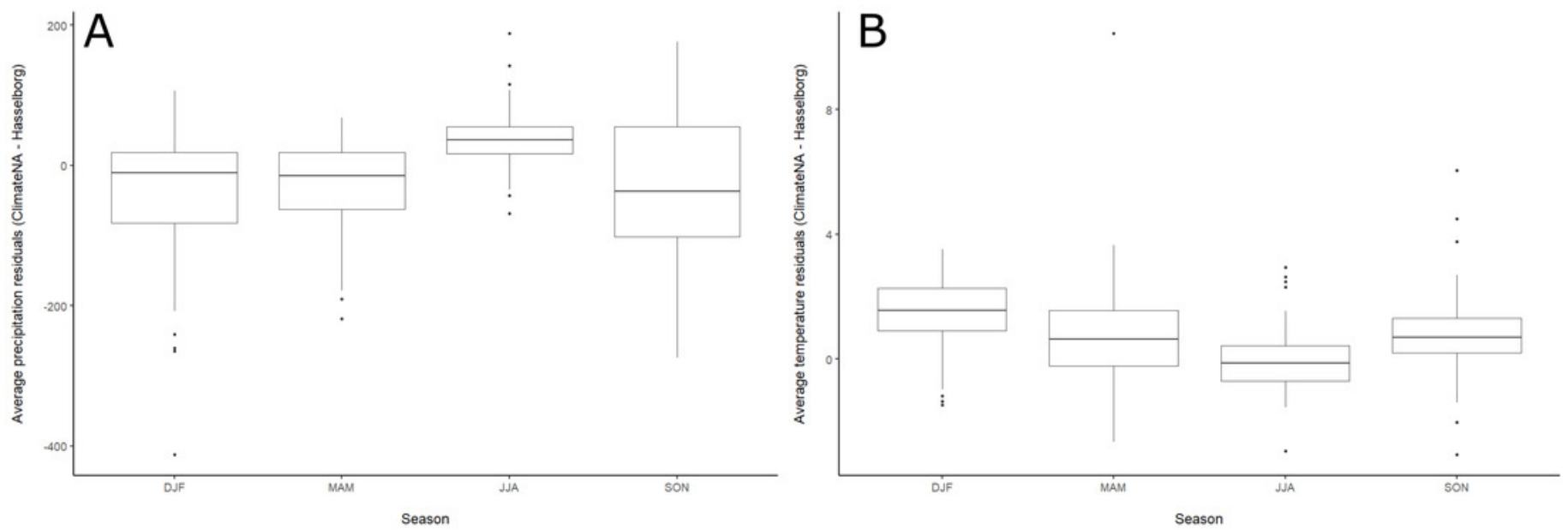


\section{Figure 6}

Spatial correlation of precipitation during a wet year.

Correlation between monthly precipitation values generated by ClimateNA and Hasselborg weather journals during 1939, the wettest year recorded in the journals. Grid cell colors correspond to the magnitude of correlation defined in the legend. Grid cells in the spatial correlation map were spaced 0.2 decimal degrees longitude and 0.1 decimal degrees latitude apart and originated from the Hasselborg homestead.

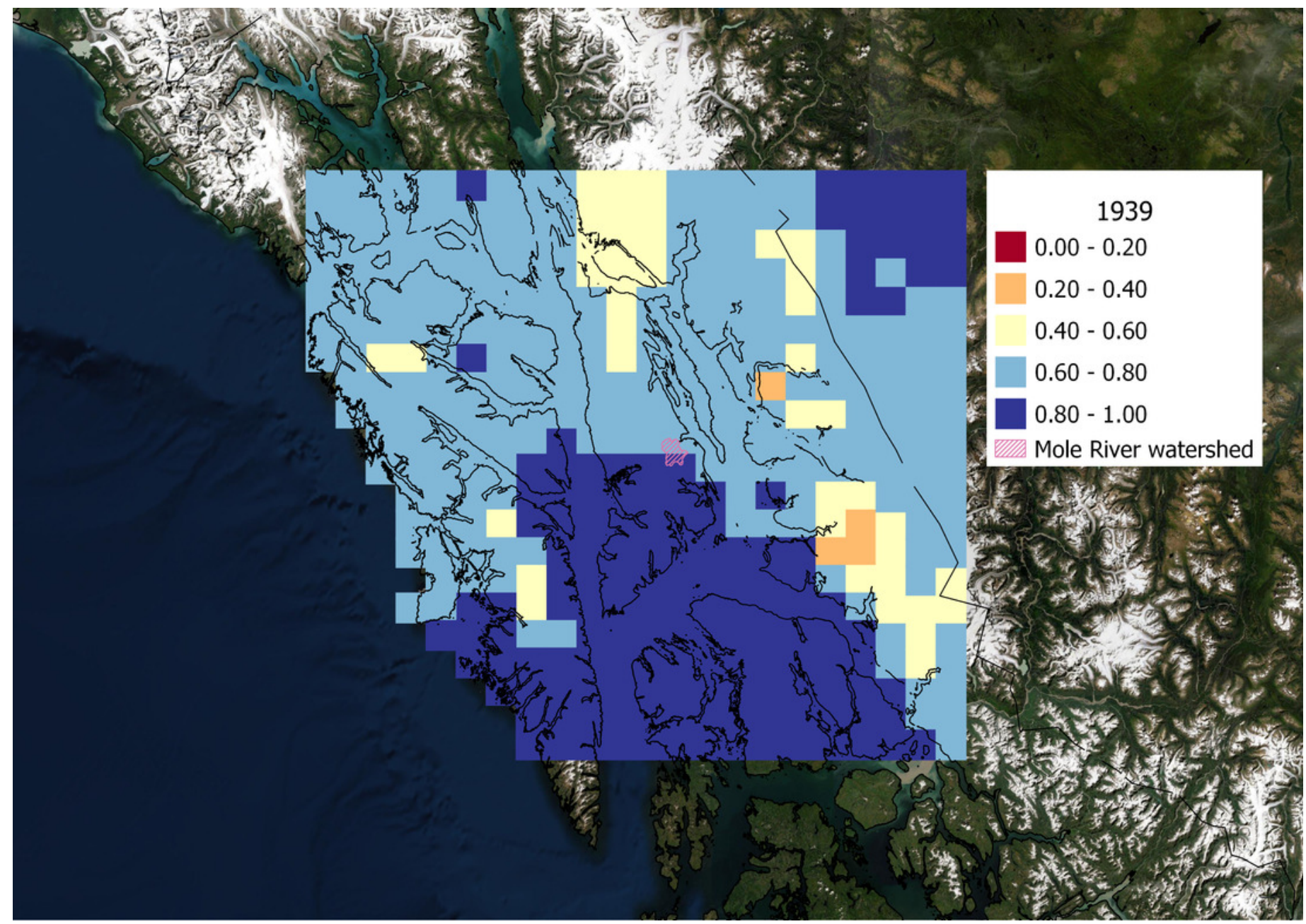




\section{Figure 7}

Spatial correlation of precipitation during a dry year.

Correlation between monthly precipitation values generated by ClimateNA and Hasselborg weather journals during 1951, the driest year recorded in the journals. Grid cell colors correspond to the magnitude of correlation defined in the legend. Grid cells in the spatial correlation map were spaced 0.2 decimal degrees longitude and 0.1 decimal degrees latitude apart and originated from the Hasselborg homestead.

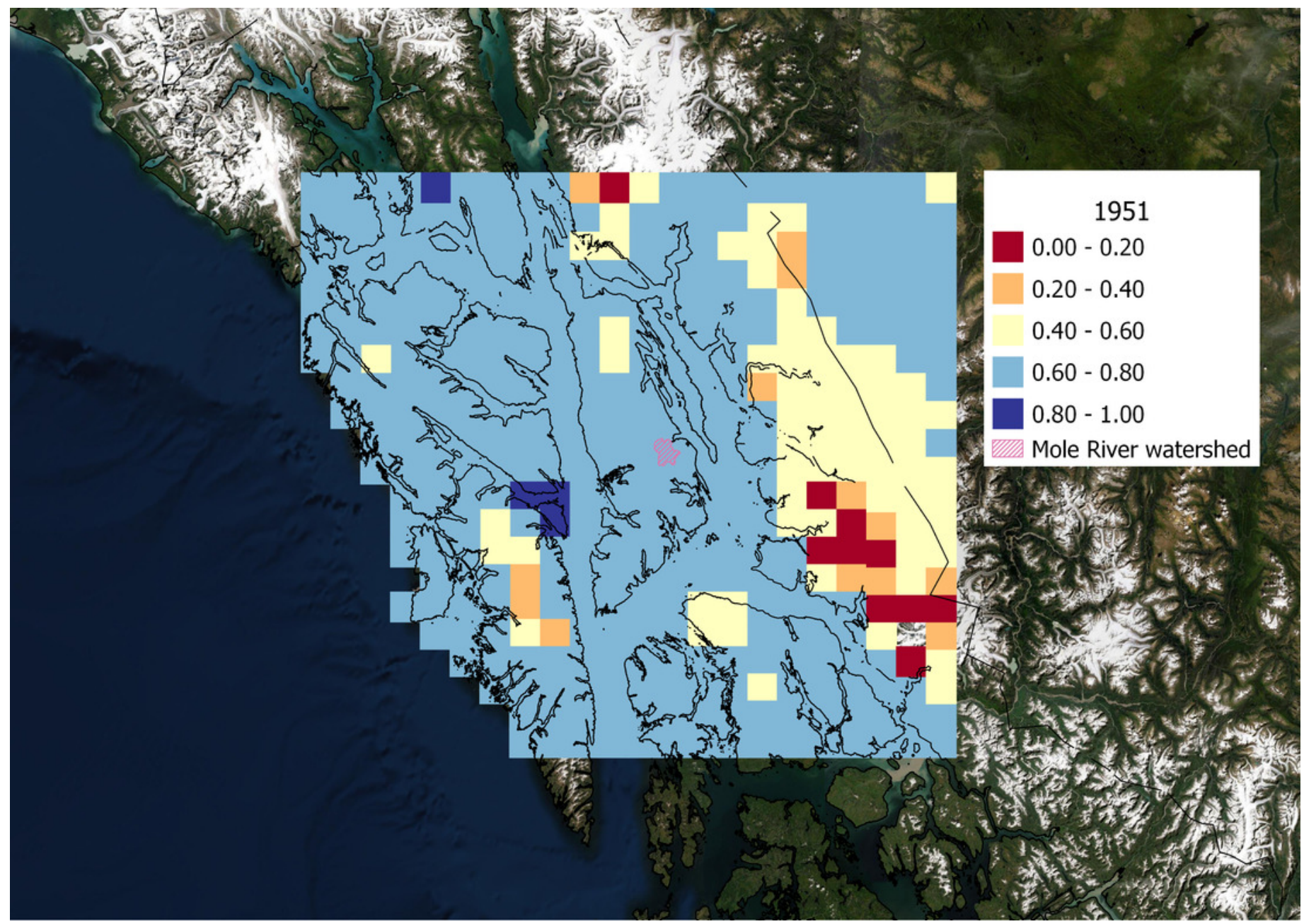


Figure 8

Using modeled and observed data to estimate low streamflow descriptors.

Annual estimates of $95 \%$ low duration flow in August using observed Hasselborg data (blue) and modeled ClimateNA data (orange).

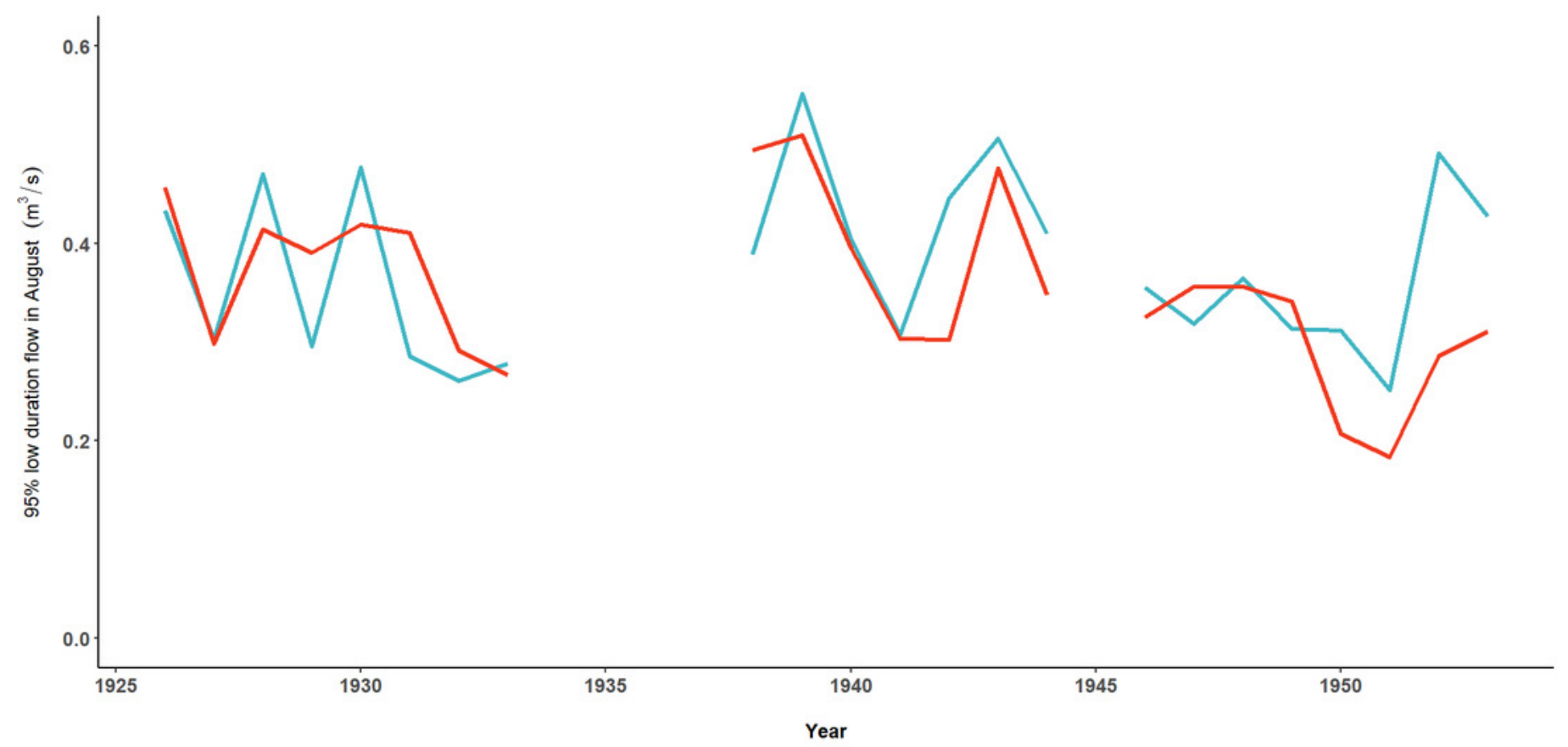

